\title{
PENINGKATAN KUALITAS SUMBER DAYA MANUSIA PEMUDA PESISIR MELALUI PELATIHAN MANAJEMEN KEPEMIMPINAN DI KECAMATAN POTO TANO KABUPATEN SUMBAWA BARAT
}

\author{
Ibrahim $^{1 *}$, Kamaluddin $^{2}$, Mas, $\mathrm{ad}^{3}$, Junadi AM ${ }^{4}$ \\ ${ }^{1 *}$ Program Studi Pendidikan Geografi, FKIP Universitas Muhammadiyah Mataram \\ ${ }^{2}$ Program Studi Pendidikan Geografi, FKIP Universitas Muhammadiyah Mataram \\ ${ }^{3}$ Program Studi Pendidikan Geografi, FKIP Universitas Muhammadiyah Mataram \\ ${ }^{4}$ Program Studi IImu Pemerintahan, FISIPOL Universitas Muhammadiyah Mataram \\ ${ }^{*}$ Corresponding author : \\ E-mail: ibrahimali.geo@gmail.com
}

Diterima 16 November 2018, Disetujui 23 November 2018

\begin{abstract}
ABSTRAK
Penelitian ini bertujuan untuk mengetahui dampak program pelatihan manajemen Kepemimpinan dalam meningkatkan Sumberdaya Manusia (SDM) kepemudaan daerah pesisir di Kecamatan Poto Tano Kabupaten Sumbawa Barat. Metode Penelitian menggunakan pendekatan deskriptif kualitatif. Pengumpulan data menggunakan wawancara mendalam dengan pihak pemuda. Analisis data dalam penelitian ini menggunakan model analisis interaktif yaitu analisis dengan menggunakan reduksi data, display data, dan verifikasi dan kesimpulan. Hasil Penelitian menunjukan bahwa pelatihan manajemen kepemimpinan kepemudaan pada daerah pesisir berdampak positif karena tercipta perubahan yang diinginkan meskipun belum nampak secara menyeluruh dari peserta yang mengikuti pelatihan. Secara keseluruhan hasil program ini diharapkan pemuda daerah pesisir di Kecamatan Poto Tano dapat memiliki beberapa keahlian yang dapat dijadikan sebagai modal dalam mengembangkan diri. Para pemuda dapat menumbuhkembangkan ketrampilan sebagai modal utama terutama pada sektor UMKM yang dipandang sangat menjanjikan keuntungan. Potensi pemuda dapat dikembangkan dengan membentuk kelompok usaha bersama, sehingga dapat kesejahteraan keluarga dan masa depan yang lebih berkemajuan.
\end{abstract}

Kata Kunci: Pelatihan Manajemen, Kepemimpinan dan Pemberdayaan Pemuda

\begin{abstract}
This study aims to determine the impact of the Leadership management training program in improving the human resources (HR) of coastal areas in the Poto Tano District of West Sumbawa Regency. The research method uses a qualitative descriptive approach. Data collection uses in-depth interviews with youth. Data analysis in this study uses an interactive analysis model that is analysis using data reduction, data display, and verification and conclusions. Research results show that youth leadership management training in coastal areas has a positive impact because it creates the desired change even though it has not been seen as a whole from the participants who attended the training. Overall the results of this program are expected that the youth in the coastal areas in Poto Tano Subdistrict can have several skills that can be used as capital in developing themselves. The youth can develop skills as the main capital, especially in the MSME sector which is seen as very promising profits. The potential of youth can be developed by forming joint business groups, so that they can get family welfare and a more developed future.
\end{abstract}

Keywords: Management Training, Youth Leadership and Empowerment

\section{PENDAHULUAN}

Pembangunan dan generasi mendatang menjadi isu penting dalam setiap event pertemuan nasional dan internasional. Menurut World Bank (2006) menjelaskan bahwa memandang kepemudaan sehubungan dengan transisi-transisi kait-mengait ini. Akan tetapi penting untuk dipahami bahwa orang muda tidak mesti memandang diri mereka dengan cara seperti itu, atau hanya dengan cara itu. Sering kali mereka sibuk mengembangkan budaya dan identitas anak muda sendiri, misalnya berusaha tampak berhasil di mata rekan-rekan sebaya mereka sebagai pemuda (bukan sebagai calon 
dewasa) dan bukan berusaha menyiapkan diri menjadi orang dewasa yang berhasil.

Pembangunan sesungguhnya pembungunan yang memperhatikan generasi saat ini dan tidak melupakan generasi masa depan. Pemudah sebagai memiliki peluang besar dalam mengembangkan negara kedepan. Menurut Hasdiansyah dan Suryono (2016) menjelaskan kaum muda sering ditafsirkan sebagai pemuda yang memiliki pengaruh besar pada kemajuan suatu negara. Indonesia dalam sejarahnya telah menunjukkan bahwa proklamasi kemerdekaan Indonesia diinisiasi oleh pemuda. Hal tersebut bisa dilihat melalui keterlibatan pemuda dalam perjuangan kemerdekaan negara Indonesia yang tidak bisa dipungkiri telah membawa angin segar bagi rakyat Indonesia. Kehadiran pemuda adalah bukti bahwa semangat juang pemuda pada saat itu sangat tinggi, nasionalisme sangat kuat dan secara radikal menolak penjajahan. Kiprah pemuda bisa dilihat dari gerakan mereka sejak sebelum momentum kebangkitan nasional hingga pasca reformasi saat ini.

Keberadaan pemuda sebagai agen perubahan di tengah masyarakat, mampu memberikan ide-ide cemerlang dalam menyelesaikan masalah-masalah yang dihadapi di tengah masyarakat. Pemuda merupakan bagian dari masyarakat sosial yang mempunyai pengaruh terhadap regenerasi dalam kehidupan masyarakat. Selain itu pemuda mempunyai peran sebagai agen of change bahwa pemuda selain mempunyai ide-ide atau gagasan yang perlu dikembangkan selain itu juga berperan sebagai peubahan negara dan bangsa ini (Suhendrik dan Ritha, 2016).

Perkembangan pemuda saat ini sangatlah kompleks dengan krisis mental sangat rendah. Generasi muda yang akan meneruskan cita-cita sebuah bangsa, untuk memimpin dan mengatur sebuah Negara. Kondisi ini haruslah memiliki kepribadian yang baik, kecerdasan yang di landasi dengan ilmu dan wawasan yang luas. Selain itu memiliki jiwa denagn semangat dan pikiran terbuka serta tujuan yang baik dengan bobot dan bermanfaat serta berguna dalam kemajuan bangsa dan Negara. Namun, generasi muda Indonesia pada saat ini telah banyak terjerumus pada dunia modernisasi dan westernisasi sehingga melupakan adat ketimuran yang kita miliki yang di kenal oleh Negara lain sebagai Negara yang menjunjung tinggi moral dan adat kesopanan, tapi fakta mengatakan lain. Generasi Indonesia saat ini mengalami krisis identitas dan korban dari gaya hidup hedonisme barat. Semakin banyak life style dari luar.

Mental menjadi sasaran utama dalam mengembangkan generasi yang memperhatikan lingkungan sosial. Tataran moral, sosial dan akademik pemuda tidak lagi memberi contoh dan keteladanan baik kepada masyarakat sebagai kaum terpelajar, lebih banyak yang berorientasi pada hedonism (berhura-hura), tidak banyak pemuda yang peka terhadap kondisi sosial masyarakat saat ini (Herawati, 2016).

Berangkat dari permasalahan pemuda secara keseluhan saat ini, tentu membutuhkan strategi tentang bagaimana cara atau strategi pengembangan sumber daya pemuda. Menurut Moerdiyanto, (2011) menguraikan pandangannya tentang strategi pembangunan pemuda yang dapat dilakukan dengan cara: 1) membangun mo-ral dan budi pekerti luhur dan suci, 2) membangun sarana prasarana fisik dan non-fisik dengan mengedepankan kepentingan bangsa dan negara tersebut kepentingan pri-badi, kelompok atau golongan, 3) membangun sumber daya manusia dengan keteladanan, solidaritas, gotong royong, sopan santun, ramah tamah, saling menghormati, dan saling menghargai, dan memelihara kepekaan social, 4) membangun semangat juang dan cinta tanah air, dan 5) membangun future mapping sebagai blue print for nation character building.

kini membutuhkan kompetensi guna memberikan jalan keluar terbaik dalam menuju generasi unggul. Menurut Lerner (2010) (Bower, Li, Kiely, Brittian, Lerner, \& Lerner (2010), Hasdiansyah dan Suryono (2016) menunjukan bahwa untuk mengembangan pemuda tentu pihak terkait atau organisasi perlu memperhatikan 5 aspek berikut, 1) aspek kompe-tensi yang meliputi (kompetensi sosial, kompetensi kognitif, kompetensi akademik, dan kompetensi kejuruan). Kompetensi sosial berkaitan dengan keterampilan intraperso-nal misalnya (resolusi konflik). Kompetensi kognitif berkaitan dengan kemampuan kog-nitif misalnya (pengambilan keputusan). Kompetensi akademik berkaitan dengan nilai ujian. Kompetensi kejuruan berkaitan dengan kebiasaan kerja, kewirausahaan dan eksplorasi karir, 2) aspek keyakinan berkait-an dengan rasa internal atau harga diri seseorang, 3) aspek koneksi berkaitan dengan hubungan pemuda dengan orang-orang di sekitarnya, seperti kerabat, keluarga, dan masyarakat umum, 4) aspek karakter berkaitan dengan rasa hormat kepada atauran dan norma sosial yang 
berlaku, moralitas, dan integritas dan 5) aspek merawat berkaitan dengan rasa simpati dan empati terhadap orang lain.

$$
\text { Terkait dilakukan pelatihan }
$$
manajemen kepemimpinan dalam rangka peningkatan kualitas Sumber Daya Manusia pemuda pesisir di Kecamatan Poto Tano Kabupaten Sumbawa Barat. Pemuda yang dimaksud adalah perwakilan masing-masing desa yang ada di Kecamatan Poto Tano dengan pusat pelaksanaan berada di Desa Tuananga. Oleh karena itu, peran semua pihak terutama perguruan tinggi dan masyarakat sangat diperlukan dalam rangka pengembangan kualitas sumber daya pemuda yang berdaya saing global.

Berdasarkan hasil pelaksanaan program pelatihan tersbut diatas, penulis tertarik meneliti masalah ini dengan secara lebih dalam. Tujuan penelitian ini adalah Untuk mengetahui dampak program pelatihan manajemen Kepemimpinan dalam meningkatkan Sumberdaya Manusia kepemudaan daerah pesisir di Kecamatan Poto Tano Kabupaten Sumbawa Barat.

\section{METODE PENELITIAN}

Kegiatan pelatihan dilaksanakan pada Hari Senin Tanggal 29 Oktober 2018 menggunakan metode pelatihan dan pendampingan. Tempat pelaksanaan pada Desa Tuananga Kec. Poto Tano Kabupaten Sumbawa Barat Provinsi Nusa Tenggara Barat.

Penelitian ini menggunakan pendekatan kualitatif deskriptif. Fokus dan tujuan penelitian ini adalah untuk mengetahui kemampuan Sumberdaya Manusia melalui pelatihan manajemen kepemimpinan kepemudaan Se-Kecamatan Poto Tano Kabupaten Sumbawa Barat. Jenis data yang digunakan dalam penelitian ini lebih banyak menggunakan data kualitatif berdasarkan hasil wawancara narasumber. Sumber Data yang digunakan: 1) data primer yaitu data yang diperoleh secara lansung dengan mengadakan wawancara langsung dengan pemuda yang mengikuti pelatihan sebagai objek penelitian, 2) Data sekunder yaitu data yang diperoleh untuk membandingkan beberapa hal terkait penelitian, seperti; hasilhasil penelitian sebelumnya dan buku-buku.

Teknik pengumpulan data menggunakan wawancara, dokumentasi, dan observasi dengan subyek penelitian yaitu Kepala Desa dan pemuda. Analisis data dalam penelitian ini menggunakan model analisis interaktif yaitu analisis dengan menggunakan reduksi data, display data, dan verifikasi dan kesimpulan

\section{HASIL DAN PEMBAHASAN}

Kecamatan Poto Tano salah satu kecamatan yang di Kabupaten Sumbawa Barat berdasarkan pada Peraturan Daerah No. 4 Tahun 2007 tentang Pembentukan Kecamatan Poto Tano dengan memiliki persebaran beberapa desa yaitu: Desa Kiantar, Mantar, Kokarlian, Poto Tano, Senayan, Tuananga, Tebo dan Tambak Sari. Pelaksanaan program pelatihan manajemen kepemimpinan kepemudaan Se-Kecamatan Poto Tano di pusatkan pada Desa Tuananga.

Hasil penelitian ini menunjukan bahwa pelatihan manajemen kepemimpinan kepemudaan daerah pesisir Se-kecamatan Poto Tano memiliki manfaat dalam meningkatkan Sumberdaya Manusia sebagai keterampilan (skill) dalam meningkatkan perekonomian keluarga dan peningkatan sumber pendapatan asli desa.

Berdasarkan hasil wawancara mendalam dengan $\mathrm{HMH}$ (Sekdes Tuananga) pada tanggal 29 Oktober 2018 menyebutkan bahwa keberadaan program pelatihan manajemen kepemimpinan kepemudaan yang dilaksanakan dari Universitas Muhammadiyah Mataram memberikan dampak positif dalam memberikan pengetahuan tentang pengembangan diri generasi muda saat ini. Di satu sisi memberikan ketrampilan diri dalam rangka menghadapi generasi global yang serba modern dan tentu perlu banyak belajar dan pelatihan mampu menberikan ketrampilan sebagai modal utama terutama pada sektor UMKM yang dipandang sangat menjanjikan keuntungan di masa kini dan akan datang.

Hal ini diperkuat dari wawancara mendalam dengan RWN (Pemuda Tuananga) pada tanggal 29 Oktober 2018 menyebutkan bahwa setelah mengikuti program pelatihan manajemen kepemimpinan kepemudaan yang dilaksanakan dari Universitas Muhammadiyah Mataram mampu mengembangkan usaha yang di miliki saat ini dengan mengetahuan yang di miliki setelah pelatihan dan mampu menemukan alternatif solusi dari setiap permasalahan yang di hadapi di lapangan terutama dalam mengembangkan usaha kecil. Usaha saat ini di jadikan aset terutama kelompok usaha bersama dari kalangan pemuda, sehingga mampu bersaing dengan pemuda lain.

Pada sisi lain, pelatihan manajemen kepemimpinan diri ini dinilai peserta pelatihan bermanfaat baginya. Hal ini diperkuat dari wawancara mendalam dengan SYF (Pemuda Tambank Sari) pada tanggal 29 Oktober 2018 menyebutkan bahwa setelah mengikuti program pelatihan manajemen kepemimpinan 
kepemudaan yang dilaksanakan dari Universitas Muhammadiyah Mataram sangat bermanfaat dalam mengembangkan diri terutama mengetahui seluk beluk dalam komunikasi dengan pihak-pihak terkait terutama dalam mengembangkan usaha. Oleh kerena itu pelatihan perlu di ulang lagi terutama fokus pada masing-masing desa, sehingga mampu memberikan motivasi pada generasi emas di desa sebagai tumpuan dalam mengembangkan roda perekonomian desa.

Berdasarkan hasil wawancara diatas peserta merasa puas karena pelatihan yang diberikan dapat memberi pengetahuan baru dan membantunya lebih bersemangat melaksanakan tugasnya. Kelebihan pelatihan ini mampu mendorong peserta untuk lebih mampu memandang situasi kerja dari sisi positif dan penyajian materi sistematis sehingga memudahkan peserta mengikuti alur pelatihan. Berdasarkan evaluasi pelatihan baik dari peserta maupun dari pengamat, pelatih dinilai mampu menghidupkan suasana pelatihan sehingga peserta tidak merasa bosan dan sebaliknya sangat tertarik untuk mendengarkan penjelasan-penjelasan dari pelatih. Evaluasi dari sisi proses penyelenggaraan pelatihan adalah fasilitas tempat pelatihan memadai dengan didukung oleh peralatan-peralatan seperti LCD, pendingin ruangan, dan lain-lain. Pendapat peserta pelatihan yang didapat dari kolom komentar umumnya menyatakan bahwa pelatihan kepemimpinan diri yang diberikan sangat bermanfaat bagi pengembangan diri serta perlu untuk secara rutin diberikan.

Dibalik kelemahan pelatihan memeiliki beberapa kelemahan yang perlu diperbaiki di masa akan datang. Terutama pendeknya waktu pelaksanaan sehingga tidak mampu untuk menerapkan hasil pelatihan secara terstruktur.

Berdasarkan temuan diatas memberika arti bahwa pelatihan ini memberikan dampak positif dalam mengembang diri para generasi muda. Menurut Nasution (2001) menjelaskan bahwa dengan adanya peningkatan keahlian, pengetahuan, dan wawasan, sikap karyawan pada tugas -tugasnya dengan pengetahuan yang didapat dalam pendidikan dan pelatihan akan merubah tingkah laku, guna mendapatkan produktivitas yang tinggi. Temuan tersebut diperkuat dari Handoko (2000) menyatakan pendidikan dan latihan mempunyai ruang lingkup yang lebih luas untuk memperbaiki dan meningkatkan pengetahuan, kemampuan, sikap dan sifatsifat kepribadian

\section{SIMPULAN}

$\begin{array}{ccr}\text { Dampak } & \begin{array}{c}\text { program } \\ \text { manajemen }\end{array} & \begin{array}{r}\text { pelatihan } \\ \text { Kepemimpinan }\end{array}\end{array}$ meningkatkan Sumberdaya Manusia kepemudaan daerah pesisir di Kecamatan Poto Tano Kabupaten Sumbawa Barat sesuai yang diharapkan. Perubahan yang dihasilkan dari pelatihan manajemen kepemimpinan kepemudaaan ini terbangun kesadaran berpikir kritis, membangun kesadaran dalam enterpreneurshif.

\section{UCAPAN TERIMAKASIH}

Pelaksanaan Pengabdian Masyarakat melalui Pelatihan manajemen kepemimpinan kepemudaan di daerah pesisir Kecamatan Poto Tano Kabupaten Sumbawa Barat melibatkan semua pihak tidak terlepas dari peran serta banyak pihak. Untuk itu Kami menyampaikan terima kasih kepada :

1. Rektor Universitas Muhammadiyah Mataram sebagai institusi dimana Pelaksana melaksanakan tugas sebagai Dosen

2. Lembaga Penelitian dan Pengabdian kepada Masyarakat (LPPM) Universitas Muhammadiyah Mataram

3. Kepala Desa Se-Kecamatan Poto Tano

4. Pemuda Se-Kecamatan Poto Tano

\section{DAFTAR RUJUKAN}

Bower, E.P., Li, Y., Kiely, M.K., Brittian, A., Lerner, J.V., \& Lerner, R.M. (2010). The five cs model of positive youth development: A longitudinal analysis of confirmatory factor structure and measurement invariance. Journal Youth Adolescence 39 (7), pp.720735. Retrived from http://link.springer.com/article/10.100 7/s10964-010-9530-9

Handoko, T. Hani, 2000, Manajemen Personalia dan Sumber Daya Manusia, Yogyakarta : Edisi 2 BPFE

Hasdiansyah, Andi Dan Suryono, Yoyon, 2016, Evaluasi Program Pelatihan Pemuda Dalam Meningkatkan SDM Di HMI Koordinator Komisariat UNM, Jurnal Pendidikan Dan Pemberdayaan Masyarakat Vol. 3, No.1, Maret 2016, Print ISSN: 23551615, Online ISSN: 2477-2992

Herawati, 2016, Wirausaha Muda dalam Peningkatan Pembangunan Pertanian, Jurnal Agrica Ekstensia. Vol. 10 No.2 hal 81-87

Moerdiyanto, 2011, Pembangunan kepemimpinan pemuda berwawasan kebangsaan dan cinta tanah air, 


\section{Diakses}

http://staff.uny.ac.id/sites/default/files /pengabdian/drs-moerdiyantompd/artikel-pengemb-

kepemimpinan-pemuda-moer.pdf, pada tanggal 11 November 2018

Nasution, MN. 2001, Manajemen Mutu Terpadu, Jakarta : PT. Ghalia Indonesia

Peraturan Daerah No. 4 Tahun 2007 tentang Pembentukan Kecamatan Poto Tano

Suhendrik, dan Ritha Fatimah Dalimunthe, 2016, Pengaruh Motivasi dan Peran Pemuda terhadap Pengembangan Usaha Kecil dan Menengah (UKM) di Kabupaten Batubara, Jurnal Mediasi Vol. II No.05 hal 89-109

World Bank, 2006, Development and the Next Generation: World Bank Report 2007, The World Bank, Washington, DC 